\title{
Pengaruh Sistem Pengendalian Intern dan Komitmen Organisasi terhadap Kualitas Laporan Keuangan Pemerintah Daerah dengan Kompetensi Sumber Daya Manusia sebagai Variabel Moderating
}

\author{
Widatul Aziyah $^{1}$, Heri Yanto ${ }^{2}$ \\ Universitas Negeri Semarang ${ }^{1,2}$ \\ widatulaziyah@gmail.com ${ }^{1}$, heri.yanto@ mail.unnes.ac.id ${ }^{2}$
}

*Penulis Korespondensi

Diajukan : 20 Januari 2022

Disetujui : 27 Januari 2022

Dipublikasi : 31 Januari 2022

\begin{abstract}
This study aims to examine the effect of the internal control system and organizational commitment on the quality of local government financial reports. The population and sample in this study used are State Civil Apparatus who work in the finance department in the OPD of Batang Regency, amounting to 88 people. Sampling was used using the purposive sampling technique. The data used is primary data in the form of a questionnaire. The data analysis used is descriptive, classical assumption test, absolute value difference test, coefficient of determination test, F test, and T-test with the help of IBM SPSS software version 25.0. This study results that there is a significant positive effect between the internal control system on the quality of local government financial reports. Organizational commitment does not effect the quality of local government financial reports. Meanwhile, the competence of human resources is not able to moderate the influence between the internal control system and organizational commitment on the quality of local government financial reports. It is recommended that further research be added to the research sample, namely the accounting department, and it is hoped that the next researcher can use moderating variables to retest the hypothesis that has no effect.
\end{abstract}

Keywords: Human Resource Competence, Internal Control System, Organizational Commitment, and Quality of Local Government Financial Reports.

\section{PENDAHULUAN}

Pembaruan yang terjadi pada berbagai aspek sektor publik mendorong pemerintah untuk mewujudkan tata kelola pemerintahan yang baik (good government governance). Kinerja pemerintahan bertransformasi untuk transparan, tertib, dan bertanggungjawab melalui penyelenggaraan pengelolaan keuangan daerah sebagai upaya pembaruan dan perwujudan tata kelola pemerintahan yang baik.

Pertanggungjawaban pemerintah daerah dalam mewujudkan tanggungjawab yang dibuat selama satu periode anggaran kepada masyarakat dituangkan pada laporan keuangan pemerintah daerah. Surastiani \& Handayani (2015) menjelaskan jika informasi keuangan yang dibuat harus memenuhi kebutuhan para pemakai dengan menyajikan informasi akuntansi yang sesuai dengan PP Nomor 71 Tahun 2010 tentang SAP.

Setiap tahun LKPD memperoleh opini audit dari BPK, laporan yang telah dihasilkan dapat dikatakan berkualitas jika laporan yang dibuat memperoleh opini audit WTP. 
Sebagaimana yang telah diatur berdasarkan UU Nomor 15 Tahun 2004 mengenai Pemeriksaan Pengelolaan dan Tanggungjawab Keuangan Negara, dimana ada empat opini yang diberikan oleh BPK yaitu: wajar tanpa pengecualian, wajar dengan pengecualian, tidak wajar, dan tidak menyatakn pendapat.

Berdasarkan IHPS Semester 1 BPK pada tahun 2019 dari 541 LKPD ditemukan permasalahan umum yang dialami oleh LKPD di Indonesia diantaranya terdapat 5.175 kelemahan SPI yang terdiri dari 1.729 terkait akuntansi dan pelaporan, 2.338 berhubungan dengan pendapatan belanja pemerintah, 1.108 terkait struktur pengendalian intern (www.bpk.go.id). Selain itu terdapat fenomena yang juga ditemukan di Jawa Tengah, mayoritas permasalahan yang kerap muncul pada laporan keuangan pada unit OPD di Jawa Tengah adalah permasalahan sistem pengendalian intern terkait aset yang masih konstan ditemukan pada setiap tahunnya meskipun mendapatkan opini WTP. Opini WTP diartikan sebagai laporan yang dibuat sesuai dengan standar yang diterapkan dan tidak ada kesalahan material dan disajikan secara wajar. Namun, faktanya masih saja ditemukan permasalahan setiap tahunnya meskipun memperoleh opini audit WTP.

Pada tahun 2019 misalnya, ditemukan permasalahan pada unit OPD di Pemerintah Kabupaten Grobogan terkait aset yakni pelaporan keuangan pada Dinas Pendidikan mengenai Berita Acara Stock Opname serta penatausahaan, pelaporan yang belum tertib dan persoalanpersoalan lain terkait aset (Ulisanti \& Asrori, 2021). Selain itu, berdasarkan LHP atas LKPD Kabupaten Batang Tahun Anggaran 2020, ditemukan adanya permasalahan terkait kelemahan pengendalian intern dalam proses pembuatan laporan keuangan di Kabupaten Batang diantaranya pengelolaan PBB Perdesaan dan Perkotaan (PBB-P2) belum optimal yang mengakibatkan potensi PBB-P2 atas aset tanah dan bangunan PT KAI serta atas aset bangunan PT BPI belum ditetapkan sehingga belum segera tertagih, penatausahaan dan pengelolaan aset tetap Tahun 2020 belum tertib (www.bpkpad.batangkab.go.id).

Berdasarkan dari penelusuran pada riset-riset sebelumnya, masih saja ditemukan ketidakkonsistenan hasil penelitian (research gap) dari beberapa peneliti terdahulu. Hasil penelitian dari Surastiani \& Handayani (2015), Karsana \& Suaryana (2017), Widari \& Sutrisno (2017), (Trisnawati \& Wiratmaja, 2018), (Dewi et al., 2019), (Widaryani \& Kiswanto, 2020), (Indrayani \& Widiastuti, 2020), (Ulisanti \& Asrori, 2021) mengatakan bahwa sistem pengendalian intern berpengaruh positif signifikan terhadap kualitas laporan keuangan. Kemudian penelitian dari Katharina et al (2019) menemukan hasil yang berbeda yaitu sistem pengendalian intern tidak berpengaruh terhadap kualitas laporan keuangan pemerintah daerah. Penelitian dari Widari \& Sutrisno (2017), (Nugroho \& Setyowati, 2019), (Murapi Ikang, 2020) menyatakan bahwa komitmen organisasi berpengaruh positif dan signifikan terhadap kualitas laporan keuangan. Bertentangan dengan penelitian Harlinda (2016), Widaryani \& Kiswanto (2020) dimana menemukan bukti jika komitmen organisasi tidak memiliki pengaruh terhadap kualitas laporan keuangan pemerintah daerah.

Berdasarkan uraian masalah yang tersebut, penelitian ini bermaksud untuk menemukan pengaruh sistem pengendalian intern dan komitmen organisasi terhadap kualitas laporan keuangan pemerintah daerah, serta ingin melihat efek kompetensi sumber daya manusia dalam memoderasi pengaruh sistem pengendalian intern dan komitmen organisasi terhadap kualitas laporan keuangan pemerintah daerah.

\section{Landasan Teori}

\section{STUDI LITERATUR}

Teori stewardship, teori goal setting, dan teori resource based merupakan teori dasar pada studi ini. Teori stewardship mendeskripsikan mengenai situasi manajemen tidak terdorong dengan tujuan individu saja, akan tetapi sasaran utamanya lebih diarahkan untuk kepentingan organisasi (Donaldson \& Davis, 1991), harapannya dengan adanya upaya peningkatan 
pelayanan publik pada sistem pengendalian intern yang diterapkan akan dapat mengoptimalkan tujuan yang ada yakni mampu menghasilkan laporan keuangan yang sesuai. Teori ini digunakan untuk menjelaskan sistem pengendalian intern. Selanjutnya, teori goal-setting mendeskripsikan bahwa tindakan seseorang diatur oleh pemikiran dan niat dalam diri seseorang (Suarmika \& Suputra, 2016), dapat dikatakan jika seseorang mampu memahami dari tujuan organisasi tentunya akan mampu meningkatkan pemahamannya. Teori ini digunakan untuk menjelaskan komitmen organisasi. Teori resource based adalah teori yang berfungsi sebagai kerangka kerja untuk menjelaskan dan memprediksi aspek yang mendasari keunggulan kompetitif dan kinerja keuangan suatu entitas (Barney et al., 2011), dengan adanya sumber daya dinilai mampu meningkatkan kinerja terutama dengan adanya kemampuan yang memadai dan kompeten. Teori ini digunakan sebagai penjelasan dari kompetensi sumber daya manusia.

\section{Penelitian Terdahulu}

Penelitian terdahulu yang mengkaji kualitas laporan keuangan pemerintah daerah telah banyak dilakukan. Beberapa penelitian tersebut merumuskan berbagai faktor. Faktor-faktor tersebut diantaranya yaitu sistem pengendalian intern (Ulisanti \& Asrori, 2021; Widaryani \& Kiswanto, 2020; Indrayani \& Widiastuti, 2020; Dewi et al., 2019; Trisnawati \& Wiratmaja, 2018; Agustina et al., 2018; Widari \& Sutrisno, 2017; Mokoginta dkk, 2017; Karsana \& Suaryana, 2017; Suarmika \& Suputra, 2016; Harlinda, 2016; Surastiani \& Handayani, 2015), pemanfaatan teknologi informasi (Ulisanti \& Asrori, 2021; Muda et al., 2017; Harlinda, 2016; Surastiani \& Handayani, 2015), kompetensi sumber daya manusia (Ulisanti \& Asrori, 2021; Indrayani \& Widiastuti, 2020; Dewi et al., 2019; Trisnawati \& Wiratmaja, 2018; Agustina et al., 2018; Mahardini \& Miranti, 2018; Karsana \& Suaryana, 2017; Muda et al., 2017; Suarmika \& Suputra, 2016; Harlinda, 2016; Surastiani \& Handayani, 2015), sistem akuntansi keuangan daerah (Widaryani \& Kiswanto, 2020; Indrayani \& Widiastuti, 2020; Muda et al., 2017; Mokoginta dkk, 2017), komitmen organisasi (Widaryani \& Kiswanto, 2020; Nugroho \& Setyowati, 2019; Widari \& Sutrisno, 2017; Suarmika \& Suputra, 2016; Harlinda, 2016), standar akuntansi pemerintahan (Mahardini \& Miranti, 2018; Karsana \& Suaryana, 2017).

\section{Pengaruh Sistem Pengendalian Intern terhadap Kualitas Laporan Keuangan Pemerintah Daerah}

Pengendalian intern merupakan faktor penting dalam pencapaian tujuan organisasi. Sehingga dalam proses penerapannya harus dilaksanakan secara maksimal, dengan pelaksanaan yang tepat akan memudahkan proses pencapaian segala tujuan yang telah dibuat pemerintah, sehingga mampu menyajikan laporan keuangan yang berkualitas (Karsana \& Suaryana, 2017). Kondisi tersebut didukung oleh teori stewardship yang dicerminkan dari kondisi organisasi yang kurang optimal dalam melakukan tugas dan fungsinya terutama dalam menyelenggarakan pengelolaan keuangan sesuai dengan peraturan dan pedoman mengenai pengendalian intern yang mencakup sistem akuntansi serta pengawasan keuangan yang dijalankan pemerintah sehingga menyebabkan belum terwujudnya pengelolaan keuangan yang baik (Donaldson \& Davis, 1991).

Pelaksanaan sistem pengendalian intern yang tepat, tentu akan dapat memberikan dampak yang signifikan pada semua kegiatan. Hal ini mendukung penelitian dari Surastiani \& Handayani (2015), Karsana \& Suaryana (2017), Widari \& Sutrisno (2017), (Trisnawati \& Wiratmaja, 2018), (Dewi et al., 2019), (Widaryani \& Kiswanto, 2020), (Indrayani \& Widiastuti, 2020), (Ulisanti \& Asrori, 2021) menemukan jika sistem pengendalian intern memiliki pengaruh yang positif signifikan terhadap kualitas laporan keuangan pemerintah daerah.

H1: Sistem pengendalian intern berpengaruh positif dan signifikan terhadap kualitas laporan keuangan pemerintah daerah. 


\section{Pengaruh Komitmen Organisasi terhadap Kualitas Laporan Keuangan Pemerintah Daerah}

Badu dkk (2019) komitmen adalah tingkatan seseorang pada sebuah organisasi dimana ingin berpatisipasi aktif dalam organisasi tersebut. Pegawai dengan komitmen yang baik akan menentukan seberapa besar pencapaian kinerjanya dalam organisasi tersebut karena tumbuhnya rasa kecintaan pada pekerjaannya (Ola dkk, 2019). Adanya komitmen organisasi akan memberikan pengaruh yang baik terutama dalam menghasilkan laporan keuangan.

Selaras dengan teori goal-setting yang menjelaskan bahwa seorang individu berkomitmen pada tujuan (Suarmika \& Suputra, 2016). Pegawai yang komitmennya baik dalam proses pencapaian tujuan organisasi, tentu hal tersebut akan memengaruhi sistem kinerjanya. Hal ini didukung penelitian dari Widari \& Sutrisno (2017), Nugroho \& Setyowati (2019), (Murapi Ikang, 2020) menyatakan bahwa komitmen organisasi berpengaruh positif signifikan terhadap kualitas laporan keuangan pemerintah daerah.

H2: Komitmen Organisasi berpengaruh positif dan signifikan terhadap kualitas laporan keuangan pemerintah daerah.

\section{Kompetensi Sumber Daya Manusia dalam Memoderasi Pengaruh Sistem Pengendalian Intern terhadap Kualitas Laporan Keuangan Pemerintah Daerah}

Pengendalian intern diartikan sebagai tindakan dan aktivitas yang dilakukan baik pimpinan maupun pegawai dalam proses pencapaian target organisasi dengan memberikan keyakinan yang memadai. Sependapat dengan teori stewardship yang menyatakan pada organisasi sektor publik pemerintah akan memberikan pelayanan kepada masyarakat dimana pemerintah memiliki tujuan bersama (Donaldson \& Davis, 1991). Menurut Agung \& Gayatri (2018) sumber daya manusia yang unggul mampu menciptakan kualitas laporan keuangan yang sesuai.

Sependapat dengan penelitian Karsana \& Suaryana (2017) yang menyatakan kompetensi yang tepat tentunya akan berdampak pada pekerjaan yang nantinya dapat dijalankan secara optimal sehingga target daripada pemerintah dapat tercapai secara maksimal, diantaranya menciptakan laporan keuangan yang berkualitas. Selaras dengan resource based theory yang mengemukakan dengan adanya kontribusi sumber daya manusia pada suatu entitas berdampak cukup besar (Barney et al., 2011). Sependapat dengan penelitian Indrayani \& Widiastuti (2020) yang mengungkapkan bahwa kompetensi sumber daya manusia mampu memperkuat hubungan sistem pengendalian intern terhadap kualitas laporan keuangan pemerintah daerah.

H3: Kompetensi sumber daya manusia mampu memoderasi pengaruh sistem pengendalian intern terhadap kualitas laporan keuangan pemerintah daerah.

\section{Kompetensi Sumber Daya Manusia dalam Memoderasi Pengaruh Komitmen Organisasi terhadap Kualitas Laporan Keuangan Pemerintah Daerah}

Kompetensi yang tepat akan membuat pegawai memahami pekerjaannya dengan baik termasuk fungsi dari pekerjaan tersebut. Semakin tinggi komitmen para pegawai maka semakin baik informasi akuntansi yang dihasilkan (Widaryani \& Kiswanto, 2020). Sejalan dengan teori goal-setting bahwa komitmen yang semakin baik dimiliki pegawai, maka akan semakin meningkatkan kinerjanya terutama dalam menciptakan laporan keuangan yang berkualitas (Suarmika \& Suputra, 2016). Faktor seperti keterampilan, pengetahuan, dan sikap yang baik sebagai pegawai akan menumbuhkan idealisme terhadap diri seorang pegawai, sehingga dapat menghasilkan kinerja yang optimal. Selaras dengan resource based theory bahwa kontribusi sumber daya manusia pada suatu entitas berpengaruh cukup besar (Barney et al., 2011). Sependapat dengan penelitian Yuliantini dkk (2017) menyampaikan bahwa kompetensi sumber daya manusia dapat memperkuat komitmen organisasi. 
H4: Kompetensi sumber daya manusia mampu memoderasi pengaruh komitmen organisasi terhadap kualitas laporan keuangan pemerintah daerah.

\section{METODE}

Penelitian ini memakai metode kuantitatif dengan menggunakan data primer. Populasi penelitian ini yaitu seluruh Aparatur Sipil Negara (ASN) yang berjumlah 6.254 orang yang bekerja pada OPD Kabupaten Batang. OPD di lingkungan Pemerintah Kabupaten Batang berjumlah 44 perangkat daerah. Teknik sampling yang dilakukan pada responden yang diambil yakni menggunakan teknik pusposive sampling dengan berdasarkan pertimbangan tertentu. Berkenaan dengan hal tersebut, diambil kriteria dengan dasar-dasar sebagai berikut: Pertama, responden yang digunakan adalah bagian keuangan yang mewakili tiap organisasi pemerintah daerah didasarkan adanya asumsi responden yang terpilih memadai karena terlibat langsung secara teknis dalam penyusunan dan pelaporan keuangan. Fokus sampel yakni bagian keuangan, dikarenakan pada setiap OPD bagian akuntansi belum tentu ada. Kedua, perwakilan 2 orang pada setiap OPD ditujukan agar persepsi dari seluruh responden dapat menyebar secara merata dan unit analisis dapat bersifat heterogen, sehingga diperoleh total sampel sebesar 88 sampel.

Tabel 1. Definisi Operasional

\begin{tabular}{|c|c|c|c|}
\hline Variabel & $\begin{array}{c}\text { Definisi Operasional } \\
\text { Variabel }\end{array}$ & Indikator & Pengukuran \\
\hline $\begin{array}{l}\text { Kualitas Laporan } \\
\text { Keuangan } \\
\text { Pemerintah Daerah } \\
\text { (Y) }\end{array}$ & $\begin{array}{l}\text { Suatu ukuran normatif yang } \\
\text { diwujudkan dalam bentuk } \\
\text { informasi akuntansi } \\
\text { sehingga mampu memenuhi } \\
\text { tujuan laporan keuangan } \\
\text { yang didalamnya mencakup } \\
\text { empat karakteristik } \\
\text { kualitatif. } \\
\text { (PP Nomor } 71 \text { Tahun 2010) }\end{array}$ & $\begin{array}{l}\text { 1. Relevan } \\
\text { 2. Andal } \\
\text { 3. Dapat } \\
\text { Dibandingkan } \\
\text { 4. Dapat Dipahami } \\
\text { (PP Nomor } 71 \text { Tahun } \\
\text { 2010) }\end{array}$ & Skala Likert \\
\hline $\begin{array}{l}\text { Sistem Pengendalian } \\
\text { Intern (X1) }\end{array}$ & $\begin{array}{l}\text { Segala proses mengenai } \\
\text { tindakan dan kegiatan yang } \\
\text { dilakukan oleh pimpinan } \\
\text { dan seluruh pegawai secara } \\
\text { terus menerus untuk } \\
\text { memberikan keyakinan } \\
\text { memadai atas tercapainya } \\
\text { tujuan organisasi melalui } \\
\text { kegiatan yang efektif dan } \\
\text { efisien, keandalan laporan } \\
\text { keuangan, pengamanan aset } \\
\text { negara, dan ketaatan } \\
\text { terhadap peraturan } \\
\text { perundang-undangan. } \\
\text { (PP Nomor } 60 \text { Tahun 2008) }\end{array}$ & $\begin{array}{l}\text { 1. Lingkungan } \\
\text { Pengendalian } \\
\text { 2. Penilaian Risiko } \\
\text { 3. Kegiatan } \\
\text { Pengendalian } \\
\text { 4. Informasi dan } \\
\text { Komunikasi } \\
\text { 5. Pemantauan } \\
\text { (PP Nomor } 60 \text { Tahun } \\
\text { 2008) }\end{array}$ & Skala Likert \\
\hline $\begin{array}{l}\text { Komitmen } \\
\text { Organisasi (X2) }\end{array}$ & $\begin{array}{l}\text { Tingkatan seseorang pada } \\
\text { sebuah organisasi dimana } \\
\text { ingin berpatisipasi aktif } \\
\text { dalam organisasi tersebut. }\end{array}$ & $\begin{array}{l}\text { 1. Komitmen Afektif } \\
\text { 2. Komitmen } \\
\text { Continue } \\
\text { 3. Komitmen } \\
\text { Normatif } \\
\end{array}$ & Skala Likert \\
\hline
\end{tabular}


Owner: Riset \& Jurnal Akuntansi

e-ISSN : 2548-9224 | p-ISSN : 2548-7507

Volume 6 Nomor 1, Januari 2022

\begin{tabular}{|c|c|c|c|}
\hline & $\begin{array}{l}\text { (Widaryani \& Kiswanto, } \\
\text { 2020) }\end{array}$ & $\begin{array}{l}\text { (Widaryani \& } \\
\text { Kiswanto, 2020) }\end{array}$ & \\
\hline $\begin{array}{l}\text { Kompetensi Sumber } \\
\text { Daya Manusia (Z) }\end{array}$ & $\begin{array}{l}\text { Sebuah kemampuan dalam } \\
\text { melakukan tugas dengan } \\
\text { dukungan aspek } \\
\text { keterampilan dan } \\
\text { pengetahuan, serta sikap } \\
\text { kerja yang dituntun dalam } \\
\text { tugas tersebut. } \\
\text { (MK Kepala Badan } \\
\text { Kepegawaian Negara RI } \\
\text { Nomor 46A Tahun 2003) }\end{array}$ & $\begin{array}{l}\text { 1. Pengetahuan } \\
\text { 2. Keterampilan } \\
\text { 3. Sikap } \\
\text { (MK Kepala Badan } \\
\text { Kepegawaian Negara } \\
\text { RI Nomor 46A Tahun } \\
\text { 2003) }\end{array}$ & Skala Likert \\
\hline
\end{tabular}

Sumber: Data diolah dari berbagai sumber, 2021

Cara pengambilan data adalah dengan menggunakan angket atau kuesioner dengan memberikan seperangkat daftar pertanyaan kepada responden untuk diisi. Pemungutan data dengan menyebarkan angket kepada Kepala Subbagian Keuangan dan Bendahara Pengeluaran pada OPD yang berkedudukan di Pemerintah Daerah Kabupaten Batang. Metode analisis data yang digunakan adalah statistik deskriptif, regresi liniear berganda, dan regresi moderasi dengan menggunakan uji nilai selisih mutlak dengan bantuan IBM SPSS versi 25.

\section{HASIL}

Pengujian statistik deskriptif bertujuan untuk mendeskripsikan mengenai masing-masing variabel penelitian. Pengujian menemukan bahwa dari seluruh variabel yang digunakan memiliki standar deviasi lebih besar dari mean yang artinya data menyebar secara beragam. Sedangkan variabel lainnya memiliki nilai standar deviasi kurang dari mean artinya data menyebar seragam.

Tabel 2. Hasil Analisis Statistik Deskriptif

\begin{tabular}{|l|r|r|r|r|r|}
\hline \multicolumn{7}{|c|}{ Descriptive Statistics } \\
\hline & \multicolumn{1}{|c|}{ N } & \multicolumn{1}{|c|}{ Minimum } & Maximum & \multicolumn{1}{c|}{ Mean } & \multicolumn{1}{c|}{$\begin{array}{c}\text { Std. } \\
\text { Deviation }\end{array}$} \\
\hline Sistem Pengendalian Intern & 88 & 52 & 75 & 62.43 & 5.725 \\
\hline Komitmen Organisasi & 88 & 13 & 35 & 25.36 & 4.597 \\
\hline $\begin{array}{l}\text { Kompetensi Sumber Daya } \\
\text { Manusia }\end{array}$ & 88 & 24 & 40 & 31.39 & 3.409 \\
\hline $\begin{array}{l}\text { Kualitas Laporan Keuangan } \\
\text { Pemerintah Daerah }\end{array}$ & 88 & 44 & 60 & 50.77 & 4.391 \\
\hline Valid N (listwise) & 88 & & & & \\
\hline
\end{tabular}

Sumber: Output SPSS, 2021

\section{Uji Instrumen}

Uji validitas ditujukan untuk menunjukkan kevalidan serta kesahihan dari pernyataan yang digunakan. Pada penelitian ini cara pengukuran validitas dilakukan dengan uji Corrected Item-Total Correlation. Pengujian validitas menggunakan taraf signifikansi sebesar $5 \%$.

Tabel 3. Hasil Uji Validitas KLKPD

\begin{tabular}{|c|c|c|c|}
\hline Item Pertanyaan & $\begin{array}{c}\text { Corrected Item- } \\
\text { Total Correlation }\end{array}$ & rtabel & Keterangan \\
\hline KLKPD1 & 452 & 361 & Valid \\
\hline
\end{tabular}


Owner: Riset \& Jurnal Akuntansi

e -ISSN : 2548-9224 | p-ISSN : 2548-7507

Volume 6 Nomor 1, Januari 2022

\begin{tabular}{|c|c|c|c|}
\hline KLKPD2 & 407 & 361 & Valid \\
\hline KLKPD3 & 423 & 361 & Valid \\
\hline KLKPD4 & 668 & 361 & Valid \\
\hline KLKPD5 & 826 & 361 & Valid \\
\hline KLKPD6 & 668 & 361 & Valid \\
\hline KLKPD7 & 780 & 361 & Valid \\
\hline KLKPD8 & 634 & 361 & Valid \\
\hline KLKPD9 & 724 & 361 & Valid \\
\hline KLKPD10 & 464 & 361 & Valid \\
\hline KLKPD11 & 807 & 361 & Valid \\
\hline KLKPD12 & 853 & 361 & Valid \\
\hline
\end{tabular}

Sumber: Data diolah, 2021

Tabel 4. Hasil Uji Validitas SPI

\begin{tabular}{|c|c|c|c|}
\hline Item Pertanyaan & $\begin{array}{c}\text { Corrected Item- } \\
\text { Total Correlation }\end{array}$ & rtabel & Keterangan \\
\hline SPI1 & 899 & 361 & Valid \\
\hline SPI2 & 820 & 361 & Valid \\
\hline SPI3 & 837 & 361 & Valid \\
\hline SPI4 & 699 & 361 & Valid \\
\hline SPI5 & 733 & 361 & Valid \\
\hline SPI6 & 617 & 361 & Valid \\
\hline SPI7 & 426 & 361 & Valid \\
\hline SPI8 & 860 & 361 & Valid \\
\hline SPI9 & 791 & 361 & Valid \\
\hline SPI10 & 692 & 361 & Valid \\
\hline SPI11 & 726 & 361 & Valid \\
\hline SPI12 & 779 & 361 & Valid \\
\hline SPI13 & 699 & 361 & Valid \\
\hline SPI14 & 487 & 361 & Valid \\
\hline SPI15 & 673 & 361 & Valid \\
\hline
\end{tabular}

Sumber: Data diolah, 2021

Tabel 5. Hasil Uji Validitas KO

\begin{tabular}{|c|c|c|c|}
\hline Item Pertanyaan & $\begin{array}{c}\text { Corrected Item- } \\
\text { Total Correlation }\end{array}$ & rtabel & Keterangan \\
\hline KO1 & 656 & 361 & Valid \\
\hline KO2 & 638 & 361 & Valid \\
\hline KO3 & 481 & 361 & Valid \\
\hline KO4 & 539 & 361 & Valid \\
\hline KO5 & 776 & 361 & Valid \\
\hline KO6 & 732 & 361 & Valid \\
\hline KO7 & 487 & 361 & Valid \\
\hline KO8 & 392 & 361 & Valid \\
\hline
\end{tabular}

Sumber: Data diolah, 2021

Tabel 6. Hasil Uji Validitas KSDM

\begin{tabular}{|c|c|c|c|}
\hline Item Pertanyaan & $\begin{array}{c}\text { Corrected Item- } \\
\text { Total Correlation }\end{array}$ & rtabel & Keterangan \\
\hline
\end{tabular}


Owner: Riset \& Jurnal Akuntansi

e-ISSN : 2548-9224 | p-ISSN : 2548-7507

Volume 6 Nomor 1, Januari 2022

\begin{tabular}{|c|c|c|c|}
\hline KSDM1 & 652 & 361 & Valid \\
\hline KSDM2 & 765 & 361 & Valid \\
\hline KSDM3 & 465 & 361 & Valid \\
\hline KSDM4 & 491 & 361 & Valid \\
\hline KSDM5 & 393 & 361 & Valid \\
\hline KSDM6 & 400 & 361 & Valid \\
\hline KSDM7 & 752 & 361 & Valid \\
\hline KSDM8 & 573 & 361 & Valid \\
\hline
\end{tabular}

Sumber: Data diolah, 2021

Uji validitas di atas dapat disimpulkan jika semua item soal pada semua variabel penelitian dinyatakan valid, terlihat dari nilai $r_{\text {hitung }}>\mathrm{rt}_{\text {abel }}$. Sehingga menandakan bahwa item soal yang dibuat dinyatakan valid dan layak untuk mengukur variabel penelitian.

Tabel 7. Hasil Uji Reliabilitas

\begin{tabular}{|l|c|c|c|c|}
\hline No & Variabel & Cronbach's Alpha & $\begin{array}{c}\text { Cronbach's Alpha } \\
\text { yang disyaratkan }\end{array}$ & Keterangan \\
\hline 1. & KLKPD & 899 & 70 & Reliabel \\
\hline 2. & SPI & 937 & 70 & Reliabel \\
\hline 3. & KO & 847 & 70 & Reliabel \\
\hline 4. & KSDM & 827 & 70 & Reliabel \\
\hline
\end{tabular}

Sumber: Data diolah, 2021

Hasil tersebut dapat disimpulkan jika semua variabel penelitian memiliki nilai cronbach's alpha > cronbach's alpha yang disyaratkan atau lebih besar dari 0,70. Sehingga dapat ditarik kesimpulan bahwa kuesioner pernyataan yang dibuat dikatakan reliabel dan layak untuk mengukur variabel penelitian.

\section{Uji Asumsi Klasik}

Tabel 8. Hasil Uji Normalitas

\begin{tabular}{|c|c|c|}
\hline \multicolumn{3}{|c|}{ One-Sample Kolmogorov-Smirnov Test } \\
\hline & & $\begin{array}{l}\text { Unstandardized } \\
\text { Residual }\end{array}$ \\
\hline \multicolumn{2}{|l|}{$\mathrm{N}$} & 88 \\
\hline \multirow[t]{2}{*}{ Normal Parameters ${ }^{\mathrm{a}, \mathrm{b}}$} & Mean & .0000000 \\
\hline & Std. Deviation & 3.09338626 \\
\hline \multirow[t]{3}{*}{ Most Extreme Differences } & Absolute & .086 \\
\hline & Positive & .086 \\
\hline & Negative & -.059 \\
\hline \multicolumn{2}{|l|}{ Test Statistic } & .086 \\
\hline \multicolumn{2}{|l|}{ Asymp. Sig. (2-tailed) } & $.118^{\mathrm{c}}$ \\
\hline \multicolumn{3}{|c|}{ a. Test distribution is Normal. } \\
\hline \multicolumn{3}{|l|}{ b. Calculated from data. } \\
\hline \multicolumn{3}{|c|}{ c. Lilliefors Significance Correction. } \\
\hline
\end{tabular}

Sumber: Output SPSS, 2021 
Uji ini menggunakan Kolmogorov-Smirnov menghasilkan data sebesar 0,086 dengan probabilitas signifikansi sebesar 0,118 dimana nilainya $>0,05$ yang berarti nilai residual pada penelitian ini berdistribusi normal.

Tabel 9. Hasil Uji Multikolonieritas

\begin{tabular}{|c|c|c|c|c|c|c|c|c|}
\hline \multicolumn{9}{|c|}{ Coefficients $^{\mathbf{a}}$} \\
\hline & & \multicolumn{2}{|c|}{$\begin{array}{c}\text { Unstandardized } \\
\text { Coefficients }\end{array}$} & \multirow{2}{*}{$\begin{array}{c}\text { Standardized } \\
\text { Coefficients } \\
\text { Beta }\end{array}$} & \multirow[b]{2}{*}{$\mathrm{T}$} & \multirow[b]{2}{*}{ Sig. } & \multicolumn{2}{|c|}{$\begin{array}{l}\text { Collinearity } \\
\text { Statistics }\end{array}$} \\
\hline \multicolumn{2}{|c|}{ Model } & B & $\begin{array}{l}\text { Std. } \\
\text { Error }\end{array}$ & & & & Tolerance & VIF \\
\hline \multirow[t]{4}{*}{1} & (Constant) & 14.548 & 3.966 & & 3.668 & .000 & & \\
\hline & $\begin{array}{l}\text { Sistem } \\
\text { Pengendalian } \\
\text { Intern }\end{array}$ & .443 & .071 & .577 & 6.230 & .000 & .688 & 1.454 \\
\hline & $\begin{array}{l}\text { Komitmen } \\
\text { Organisasi }\end{array}$ & .014 & .081 & .015 & .172 & .864 & .812 & 1.231 \\
\hline & $\begin{array}{l}\text { Kompetensi } \\
\text { Sumber Daya } \\
\text { Manusia }\end{array}$ & .262 & .117 & .203 & 2.230 & .028 & .710 & 1.408 \\
\hline
\end{tabular}

Sumber: Output SPSS, 2021

Uji tersebut menunjukkan bahwa nilai tolerance untuk variabel independen $>0,10$ dan nilai VIF untuk variabel independen $<10$. Dapat disimpulkan, jika tidak terjadi multikolonieritas antar variabel independen dalam model penelitian ini.

Tabel 10. Hasil Uji Heteroskedastisitas

\begin{tabular}{|c|c|c|c|c|c|c|}
\hline \multicolumn{7}{|c|}{ Coefficients $^{\mathrm{a}}$} \\
\hline & & \multicolumn{2}{|c|}{$\begin{array}{l}\text { Unstandardized } \\
\text { Coefficients }\end{array}$} & \multirow{2}{*}{$\begin{array}{c}\begin{array}{c}\text { Standardized } \\
\text { Coefficients }\end{array} \\
\text { Beta }\end{array}$} & \multirow[b]{2}{*}{$\mathrm{t}$} & \multirow[b]{2}{*}{ Sig. } \\
\hline \multicolumn{2}{|c|}{ Model } & $\mathrm{B}$ & Std. Error & & & \\
\hline \multirow[t]{4}{*}{1} & (Constant) & -1.269 & 2.335 & & -.544 & .588 \\
\hline & $\begin{array}{l}\text { Sistem Pengendalian } \\
\text { Intern }\end{array}$ & .068 & .042 & .211 & 1.636 & .106 \\
\hline & Komitmen Organisasi & -.036 & .048 & -.089 & -.750 & .456 \\
\hline & $\begin{array}{l}\text { Kompetensi Sumber } \\
\text { Daya Manusia }\end{array}$ & .012 & .069 & .021 & .167 & .867 \\
\hline & ependent Variable: $\mathrm{AB}$ & & & & & \\
\hline
\end{tabular}

Sumber: Output SPSS, 2021

Hasil data tersebut dapat disimpulkan bahwa nilai probabilitas signifikansinya $>0,05$ maka variabel yang disajikan pada penelitian ini tidak terdapat heteroskedastisitas dengan menggunakan metode glejser.

Tabel 11. Hasil Uji F

\begin{tabular}{|l|l|r|r|r|r|c|}
\hline \multicolumn{7}{|c|}{ ANOVA $^{\mathrm{a}}$} \\
\hline \multirow{3}{*}{ Model } & $\begin{array}{c}\text { Sum of } \\
\text { Squares }\end{array}$ & Df & Mean Square & F & Sig. \\
\hline \multirow{3}{*}{1} & Regression & 847.199 & 5 & 169.440 & 16.735 & $.000^{\mathrm{b}}$ \\
\cline { 2 - 7 } & Residual & 830.256 & 82 & 10.125 & & \\
\cline { 2 - 7 } & Total & 1677.455 & 87 & & & \\
\hline
\end{tabular}


b. Predictors: (Constant), Moderasi_2, Zscore: Komitmen Organisasi, Moderasi_1,

Zscore: Kompetensi Sumber Daya Manusia, Zscore: Sistem Pengendalian Intern

\section{Sumber: Output SPSS, 2021}

Uji $\mathrm{F}$ menunjukkan bahwa $\mathrm{F}$ hitung sebesar 16,735 dan nilai signifikansinya adalah 0,000. Angka signifikansi < 0,05, maka dapat dikatakan bahwa Moderasi_2, Zscore (KO), Moderasi_1, Zscore (KSDM), dan Zscore (SPI) secara bersama-sama memengaruhi kualitas laporan keuangan pemerintah daerah.

Tabel 12. Hasil Uji Koefisien Determinasi

\begin{tabular}{|l|r|r|r|c|}
\hline \multicolumn{5}{|c|}{ Model Summary } \\
\hline Model & $\mathrm{R}$ & R Square & Adjusted R Square & $\begin{array}{c}\text { Std. Error of the } \\
\text { Estimate }\end{array}$ \\
\hline 1 & $.711^{\mathrm{a}}$ & .505 & .475 & 3.18199 \\
\hline $\begin{array}{l}\text { a. Predictors: (Constant), Moderasi_2, Zscore: Komitmen Organisasi, Moderasi_1, } \\
\text { Zscore: Kompetensi Sumber Daya Manusia, Zscore: Sistem Pengendalian Intern }\end{array}$ \\
\hline
\end{tabular}

Sumber: Output SPSS, 2021

Adjusted $R^{2}$ pada data tersebut sebesar 0,475. Data tersebut bermakna bahwa $47,5 \%$ variabel kualitas laporan keuangan pemerintah daerah dapat diuraikan oleh variabel independen pada penelitian ini. Serta variabel moderating, selebihnya 52,5\% dijelaskan oleh faktor eksternal. Persamaan regresi ditunjukkan oleh persamaan berikut.

KLKPD $=50,868+2,934$ Zscore SPI + 0,228 Zscore KO - 0,064 Moderasi_1 - 0,051 Moderasi_2

Tabel 13. Hasil Uji Hipotesis

\begin{tabular}{|l|l|c|c|c|}
\hline No & \multicolumn{1}{|c|}{ Hipotesis } & $\begin{array}{c}\text { Koefisien } \\
\text { Regresi }\end{array}$ & Sig & Hasil \\
\hline 1. & $\begin{array}{l}\text { Sistem pengendalian intern berpengaruh positif } \\
\text { signifikan terhadap kualitas laporan keuangan } \\
\text { pemerintah daerah }\end{array}$ & 2,934 & 0,000 & Diterima \\
\hline 2. & $\begin{array}{l}\text { Komitmen organisasi berpengaruh positif } \\
\text { signifikan terhadap kualitas laporan keuangan } \\
\text { pemerintah daerah }\end{array}$ & 0,228 & 0,556 & Ditolak \\
\hline 3. & $\begin{array}{l}\text { Kompetensi sumber daya manusia memperkuat } \\
\text { pengaruh sistem pengendalian intern terhadap } \\
\text { kualitas laporan keuangan pemerintah daerah }\end{array}$ & $-0,064$ & 0,913 & Ditolak \\
\hline 4. & $\begin{array}{l}\text { Kompetensi sumber daya manusia memperkuat } \\
\text { pengaruh komitmen organisasi terhadap kualitas } \\
\text { laporan keuangan pemerintah daerah }\end{array}$ & $-0,051$ & 0,921 & Ditolak \\
\hline
\end{tabular}

Sumber: Output SPSS, 2021

\section{PEMBAHASAN}

\section{Sistem Pengendalian Intern Berpengaruh Positif dan Signifikan terhadap Kualitas Laporan Keuangan Pemerintah Daerah}

Sejalan dengan teori stewardship yang menjelaskan bahwa pada organisasi sektor publik pemerintah akan memberikan pelayanan kepada masyarakat dimana pemerintah memiliki tujuan bersama (Donaldson \& Davis, 1991). Pemerintah diharuskan menyajikan informasi yang bermanfaat sebagai wujud pertanggungjawaban kepada masyarakat. Adanya pengendalian intern yang baik akan memudahkan proses pencapaian target yang telah dibuat 
pemerintah, sehingga mampu menciptakan informasi keuangan yang berkualitas (Karsana \& Suaryana, 2017). Sependapat dengan penelitian Surastiani \& Handayani (2015), Widari \& Sutrisno (2017), (Trisnawati \& Wiratmaja, 2018), (Dewi et al., 2019), (Widaryani \& Kiswanto, 2020), (Indrayani \& Widiastuti, 2020), (Ulisanti \& Asrori, 2021).

\section{Komitmen Organisasi Berpengaruh Positif dan Signifikan terhadap Kualitas Laporan Keuangan Pemerintah Daerah}

Tingginya komitmen yang dimiliki oleh pegawai tidak menjamin akan memengaruhi kinerjanya. Sebab, komitmen berkaitan erat dengan kinerja yang berarti penting untuk organisasi menumbuhkan komitmen pada setiap pegawainya. Semakin besar komitmen yang dimiliki oleh seorang pegawai akan semakin berkualitas informasi akuntansi yang dihasilkan (Widaryani \& Kiswanto, 2020). Bertentangan dengan teori goal-setting yang menyatakan bahwa seorang individu dengan komitmen yang baik dalam pencapaian tujuan organisasinya maka akan memengaruhi kinerjanya (Suarmika \& Suputra, 2016). Sependapat dengan penelitian (Harlinda, 2016), (Widaryani \& Kiswanto, 2020).

\section{Kompetensi Sumber Daya Manusia Memperkuat Pengaruh Sistem Pengendalian Intern terhadap Kualitas Laporan Keuangan Pemerintah Daerah}

Selaras dengan teori resource based bahwa sumber daya yang unggul akan mampu mendorong terciptanya kinerja yang optimal dalam organisasi terutama dalam proses penyajian laporan keuangan. Kompetensi yang mendukung tentu akan memberikan kesadaran penuh terhadap penerapan sistem pengendalian intern dalam organisasi. Selain itu, dalam menghasilkan laporan keuangan yang baik tentu perlu didorong dengan sumber daya yang kompeten dan memadai terutama mengenai pemahaman di bidang akuntansi maupun keuangan. Oleh sebab itu, apabila sumber daya manusia tidak didukung dengan kompetensi yang memadai tentu hal tersebut akan memengaruhi penerapan sistem pengendalian internnya menjadi kurang maksimal.

\section{Kompetensi Sumber Daya Manusia Memperkuat Pengaruh Komitmen Organisasi terhadap Kualitas Laporan Keuangan Pemerintah Daerah}

Komitmen yang tidak disertai dengan kompetensi yang mendukung tentu akan memengaruhi kinerjanya, sebab pada OPD Kabupaten Batang masih banyak pegawai yang belum kompeten dalam bidang akuntansi dan di bagian keuangan masih didominasi oleh bidang lain selain akuntansi. Berdasarkan data statistik responden menunjukkan bahwa pegawai yang memiliki kompetensi akuntansi sebesar $29,5 \%$ selain itu diluar kompetensi akuntansi. Kompetensi yang rendah tentunya akan berpengaruh terhadap komitmen para pegawai. Komitmen yang semakin tinggi dimiliki pegawai akan semakin berkualitas informasi akuntansi yang dihasilkan (Widaryani \& Kiswanto, 2020). Penjelasan tersebut tidak selaras dengan teori goal-setting yang menyatakan pegawai dengan komitmen yang baik dalam pencapaian tujuan organisasi, maka akan memengaruhi kinerjanya (Suarmika \& Suputra, 2016). Sependapat dengan teori resource based yang dikemukakan oleh (Barney et al., 2011), yang menyatakan bahwa sumber daya yang unggul akan mampu mendorong terciptanya kinerja yang optimal sehingga target dari organisasi dapat tercipta seperti proses penyajian laporan keuangan dengan kualitas yang baik.

\section{KESIMPULAN}

Simpulan dari penelitian yang telah dilakukan membuktikan bahwa terdapat pengaruh positif signifikan antara sistem pengendalian intern terhadap kualitas laporan keuangan pemerintah daerah. Semantara itu, komitmen organisasi tidak memberikan pengaruh terhadap 
kualitas laporan keuangan pemerintah daerah. Kemudian kompetensi sumber daya manusia tidak mampu memoderasi hubungan sistem pengendalian intern dan komitmen organisasi terhadap kualitas laporan keuangan pemerintah daerah. Penelitian selanjutnya disarankan dapat menambah sampel penelitian yaitu bagian akuntansi, dan harapannya peneliti berikutnya dapat menggunakan variabel moderating untuk menguji kembali hipotesis yang tidak berpengaruh.

\section{DAFTAR PUSTAKA}

Agung, T. M., \& . G. (2018). Analisis Faktor-Faktor yang Mempengaruhi Kualitas Laporan Keuangan Pemerintah Daerah Kabupaten Karangasem. E-Jurnal Akuntansi, 23, 1253. https://doi.org/10.24843/eja.2018.v23.i02.p17

Agustina, M., Lubis, T. A. S., \& Muda, I. (2018). Various Aspects of The Implementation of SIMDA Which Influence The Quality of Financial Statement with The Role of PPK-SKPD as Moderating Variable (A Case Study at The SKPD of Deli Serdang Regency). 46(Ebic 2017). https://doi.org/10.2991/ebic-17.2018.28

Andi Batari Ola, Rasyidin Abdullah, M. A. (2019). Puskesmas Kajuara in Bone Regency YUME : Journal of Management. 2(1).

Ayu Yuliantini, P., Putra Astika, I. B., \& Badera, D. N. (2017). Pengaruh Kompetensi Sumber Daya Manusia, Motivasi dan Lingkungan Kerja pada Komitmen Organisasi dan Implikasinya pada Kinerja Pengurus Barang Pemerintah Kabupaten Tabanan. E-Jurnal Ekonomi Dan Bisnis Universitas Udayana, 10, 3697. https://doi.org/10.24843/eeb.2017.v06.i10.p10

Badu, I., Awaluddin, I., \& Mas'ud, A. (2019). Pengaruh Partisipasi Penyusunan Anggaran, Komitmen Organisasi, Pengaruh Partisipasi Penyusunan Anggaran, Komitmen Organisasi, Profesionalisme, Gaya Kepemimpinan, Dan Struktur Organisasi Profesionalisme, Gaya Kepemimpinan, Dan Struktur Organisasi Terhadap. Jurnal Progres Ekonomi Pembangunan, 4(3), 99-113.

Barney, J. B., Ketchen, D. J., \& Wright, M. (2011). The future of resource-based theory: Revitalization or decline? Journal of Management, 37(5), 1299-1315. https://doi.org/10.1177/0149206310391805

Dewi, N. F., Ferdous Azam, S. M., \& Yusoff, S. K. M. (2019). Factors influencing the information quality of local government financial statement and financial accountability. Management Science Letters, 9(9), 1373-1384. https://doi.org/10.5267/j.msl.2019.5.013

Donaldson, L., \& Davis, J. H. (1991). Stewardship Theory or Agency Theory: CEO Governance and Shareholder Returns. Australian Journal of Management, 16(1), 49-64. https://doi.org/10.1177/031289629101600103

Harlinda, H. (2016). Analisis Faktor-faktor yang Mempengaruhi Kualitas Informasi Laporan Keuangan Pemerintah Daerah (Studi Empiris pada Pemerintah Kabupaten/Kota di Provinsi Riau). Sorot, 11(2), 127. https://doi.org/10.31258/sorot.11.2.3890

I Wayan Karsana, I. G., \& Suaryana, N. A. (2017). Pengaruh Efektivitas Penerapan Sap, Kompetensi Sdm, Dan Spi Pada Kualitas Laporan Keuangan Pemerintah Kabupaten Bangli. E-Jurnal Akuntansi, 21(1), 643-670.

Indrayani, K. D., \& Widiastuti, H. (2020). Pengaruh Penerapan Sistem Akuntansi Keuangan Pemerintah Daerah dan Sistem Pengendalian Internal Terhadap Kualitas Laporan Keuangan Pemerintah Daerah Dengan Kompetensi Sumber Daya Manusia Sebagai Variabel Moderasi (Studi Empiris Pada Satuan Kerja Perangkat. Reviu Akuntansi Dan Bisnis Indonesia, 4(1), 1-16. https://doi.org/10.18196/rab.040148

Katharina, M. G. G., Mulyadi, J., \& Syam, M. A. (2019). Katharina Maria Goreti Goo , JMV . Mulyadi , M . Ardiansyah Syam Pemerintah Daerah Kabupaten Ende. Ekobisman, 4(2), 94-109.

Mahardini, N. Y., \& Miranti, A. (2018). Dampak Penerapan Standar Akuntansi Pemerintahan 
Dan Kompetensi Sumber Daya Manusia Pada Kualitas Laporan Keuangan Pemerintah Provinsi Banten Tahun Anggaran 2015. Jurnal Akuntansi : Kajian Ilmiah Akuntansi (JAK), 5(1), 22. https://doi.org/10.30656/jak.v5i1.500

Menurut Keputusan Kepala Badan Kepegawaian Negara RI Nomor 46A Tahun 2003 tentang Kompetensi Sumber Daya Manusia

Mokoginta, N., Lambey, L., \& Pontoh, W. (2017). Pengaruh Sistem Pengendalian Intern Dan Sistem Akuntansi Keuangan Daerah Terhadap Kualitas Laporan Keuangan Pemerintah. Going Concern: Jurnal Riset Akuntansi, 12(2), 874-890. https://doi.org/10.32400/gc.12.2.18282.2017

Muda, I., Wardani, D. Y., Erlina, Maksum, A., Lubis, A. F., Bukit, R., \& Abubakar, E. (2017). The influence of human resources competency and the use of information technology on the quality of local government financial report with regional accounting system as an intervening. Journal of Theoretical and Applied Information Technology, 95(20), 55525561.

Murapi, I. (2020). Pengaruh Sitem Akuntansi Keuangan Daerah, Pemanfaatan Teknologi Informasi, Komitmen Organisasi Terhadap Kualitas Informasi Laporan Keuangan Pemerintah Daerah Kabupaten Lombok Tengah. Riset, Ekonomi, Akuntansi Dan Perpajakan (Rekan), 1(1), 1-9. https://doi.org/10.30812/rekan.v1i1.660

Nugroho, F. A., \& Setyowati, W. (2019). Pengaruh Komitmen Organisasional, Sistem Informasi Akuntansi, Dan Peran Audit Internal Terhadap Kualitas Laporan Keuangan. ECONBANK: Journal of Economics and Banking, 1(2), 125-134. https://doi.org/10.35829/econbank.v1i2.45

Peraturan Pemerintah Nomor 71 Tahun 2010 tentang Standar Akuntansi Pemerintahan

Suarmika, I. G. L., \& Suputra, I. D. G. D. (2016). Kemampuan Komitmen Organisasi dan Sistem Pengendalian Intern Memoderasi Pengaruh Kapasitas Sumber Daya Manusia dan Penerapan SIKD Pada Kualitas LKPD Kabupaten KarangAsem. E-Jurnal Ekonomi Dan Bisnis, 5.9, 2921-2950.

Surastiani, D. P., \& Handayani, B. D. (2015). Analisis Faktor-faktor Yang Mempengaruhi Kualitas Informasi Laporan Keuangan Pemerintah Daerah. Jurnal Dinamika Akuntansi, 7, No. 2,(ISSN 2085-4277), 139-149.

Trisnawati, N. N., \& Wiratmaja, D. N. (2018). Pengaruh Kualitas Sumber Daya Manusia dan Sistem Pengendalian Intern pada Kualitas Laporan Keuangan Pemerintah Daerah. EJurnal Akuntansi, 24, 768. https://doi.org/10.24843/eja.2018.v24.i01.p29

Ulisanti Lativa, A. (2021). Human Resource Competence As A Moderating Variable For The Quality Of Local Government Financial Reports. International Journal of Economics, Business and Accounting Research, 2021(2), 505-518.

Widari, L., \& Sutrisno. (2017). Pengaruh Sistem Pengendalian Internal Pemerintah dan Komitmen Organisasi Terhadap Kualitas Laporan Keuangan Daerah. Jurnal Ilmiah Ilmu Ekonomi, 5(10), 117-126.

Widaryani, H. U., \& Kiswanto. (2020). Analysis of Factors Affecting the Quality of Local Government Financial Statements. Accounting Analysis Journal, 9(1), 53-59. https://doi.org/10.15294/aaj.v9i1.23123 